\title{
The Isolation of Cell Surface Mutants of Acinetobacter calcoaceticus RAG-1
}

\author{
By EDWARD A. BAYER, E. ROSENBERG AND D. GUTNICK* \\ Department of Microbiology, George S. Wise Faculty of Life Sciences, Tel Aviv University, \\ Ramat Aviv, Israel
}

(Received 5 January 1981; revised 20 April 1981)

The isolation of cell surface mutants of Acinetobacter calcoaceticus RAG-1 was demonstrated by a method based on the differential immunoprecipitating properties of wild-type cells and mutants. In the presence of antiserum, about $99 \%$ of wild-type cells in suspension sedimented following overnight agglutination. The kinetics of antiserum-induced agglutination was quantified by measuring the time-dependent decrease in turbidity. For mutant isolation, a sample of the cells remaining in the supernatant fluid served as inoculum for a fresh culture. This enrichment procedure of sequential growth and agglutination was repeated until the supernatant fluid following the overnight agglutination step remained turbid. Of the 40 colonies isolated in this manner, 34 exhibited altered agglutination properties.

The agglutinability of wild-type cells varied with the phase of growth - cells harvested during the exponential phase were agglutinated better than those in stationary phase. In contrast, the antiserum-induced agglutination of most mutants was poor during the early phases of growth, but improved during late-stationary phase. One mutant failed to agglutinate in the presence of antiserum irrespective of the phase of growth.

\section{INTRODUCTION}

Acinetobacter calcoaceticus RAG-1 is a Gram-negative, petroleum-degrading bacterium isolated from tar sediments contaminating a local beach (Reisfeld et al., 1972). The degradation of crude oil by this micro-organism is accompanied by dispersion of the hydrocarbon substrate in the growth medium. This emulsification is mediated by an extracellular, macromolecular emulsifier (termed 'emulsan').

Emulsan, a polysaccharide containing $15 \%(\mathrm{w} / \mathrm{w})$ covalently linked fatty acid, has a molecular weight of approximately $10^{6}$ and a reduced viscosity of $500 \mathrm{ml} \mathrm{g}^{-1}$ (Rosenberg et al., 1979). The major components of the heteropolysaccharide backbone are D-galactosamine and an unidentified amino uronic acid. The major emulsan-bound fatty acids, attached primarily via $O$-ester linkages, are $\alpha$ - and $\beta$-hydroxydodecanoic acids (Belsky et al., 1979). Antiserum prepared against partially purified emulsan agglutinated washed cells of $A$. calcoaceticus RAG-1, indicating that the antigenic determinant(s) are closely associated with the cell surface (Bayer et al., 1980).

In the present communication we describe mutants of $A$. calcoaceticus RAG-1 which exhibit altered cell surface properties. Such mutants were isolated by virtue of their non-agglutination with antiserum and were characterized with respect to the antibodymediated agglutination of cells. In addition, emulsifying properties and immunological cross-reactivity of the cell-free growth media of mutant strains were compared with those of the parent strain. 


\section{METHODS}

Organism and growth conditions. Acinetobacter calcoaceticus ATCC 31012 RAG-92, a lysine-requiring auxotroph of the original isolate (Reisfeld et al., 1972), was the parental bacterial strain used for these studies. Cells were grown with gyratory shaking at $200 \mathrm{rev} . \mathrm{min}^{-1}$ in liquid cultures in minimal medium of the following composition: 0.15 M-potassium phosphate buffer, $\mathrm{pH} 7.0,0.8 \mathrm{mM}-\mathrm{MgSO}_{4}, 3 \mathrm{~mm}-\left(\mathrm{NH}_{4}\right)_{2} \mathrm{SO}_{4}, 2.5 \%(\mathrm{v} / \mathrm{v})$ ethanol and $100 \mu \mathrm{g}$ lysine $\mathrm{ml}^{-1}$. Stock cultures were kept at $4{ }^{\circ} \mathrm{C}$ on plates containing the same minimal medium solidified with $2 \%(w / v)$ agar.

Exponential phase cells were obtained by using a $0.1 \%(\mathrm{v} / \mathrm{v})$ inoculum of a $5 \mathrm{~h}$ culture and harvesting cells at a turbidity of 40 to 50 Klett units (K.U.) (measured in a Klett-Summerson colorimeter with green filter). Stationary phase celis were generally harvested after $3 \mathrm{~d}$ growth (between 500 and $800 \mathrm{~K}$.U.).

TYE medium consisted of $1 \%(w / v)$ Bacto-Tryptone (Difco), $0.5 \%(w / v)$ yeast extract (Difco), $0.23 \%(w / v)$ $\mathrm{MgSO}_{4} \cdot 7 \mathrm{H}_{2} \mathrm{O}$ and $1 \%(\mathrm{w} / \mathrm{v}) \mathrm{NaCl}$.

Acinetobacter calcoaceticus BD413 trpE27 was kindly provided by Dr E. Juni (Department of Microbiology, University of Michigan) and was grown as described above. Escherichia coli B was obtained from Dr E. Z. Ron (Department of Microbiology, Tel Aviv University) and grown in nutrient broth.

Antisera and immunochemical techniques. Antisera against partially purified emulsan fractions (PPE fractions) were prepared as described previously (Zuckerberg et al., 1979). The material used for injection was prepared by ammonium sulphate precipitation of cell-free supernatant fluid and contained about $15 \%(\mathrm{w} / \mathrm{w})$ non-covalently bound protein. The material appeared homogeneous with respect to several criteria, including double immunodiffusion, ultracentrifugation and gel filtration. Rabbits were subjected to weekly subcutaneous injections of the emulsan preparation $(0.25$ to $1.0 \mathrm{mg})$ suspended in Freund's complete adjuvant. The titre of a given antiserum preparation was determined by haemagglutination of emulsan-conjugated sheep erythrocytes (Faulk \& Houba, 1973). Antiserum preparations were sterilized by passage through Millipore filters (HAWP-45). Double immunodiffusion of the antiserum versus either purified emulsan fractions (Rosenberg et al., 1979) or cell-free supernatants was carried out according to Ouchterlony (1958).

Isolation of cell surface emulsan mutants. An overnight culture was diluted 1 to 100 into fresh ethanol growth medium and incubated with shaking for $24 \mathrm{~h}$. A $0.1 \mathrm{ml}$ inoculum from this culture was then introduced without shaking into $10 \mathrm{ml}$ of minimal medium (lacking a carbon source) saturated with diethyl sulphate as the mutagen. After incubating the suspension without shaking for $1 \mathrm{~h}$ at $30^{\circ} \mathrm{C}$, a $0.2 \mathrm{ml}$ sample was transferred to ethanol growth medium $(10 \mathrm{ml})$ and the culture was allowed to grow to early-stationary phase $(48 \mathrm{~h}$ growth). The cells were then washed three times with $0.15 \mathrm{M}-\mathrm{NaCl}$ under sterile conditions and brought to a concentration of about $10^{10}$ cells $\mathrm{ml}^{-1}$ in a final volume of 1 to $4 \mathrm{ml}$. Whole PPE antiserum was diluted 10 -fold by direct addition to the cell suspension. After about $1 \mathrm{~h}$, extensive agglutination of the bacterial cells was observed. The agglutinated cells were allowed to settle overnight at $4^{\circ} \mathrm{C}$, and $0.2 \mathrm{ml}$ of the clear supernatant was then used to inoculate $10 \mathrm{ml}$ of fresh medium. After 16 to $24 \mathrm{~h}$ growth, the cells were again harvested, washed three times and subjected to a similar treatment with PPE antiserum. After four to five such cycles, the supernatant fluid following antiserum-induced agglutination of cells remained turbid, indicating that a significant fraction of the cells were less reactive to the antiserum. A sample from the turbid supernatant was streaked on to agar plates of minimal ethanol medium and single colonies were isolated and examined for agglutinability. To ensure that isolated colonies were not the result of contamination, they were examined for growth on solid medium lacking lysine.

Agglutinability assay. Bacteria were washed three times with $20 \mathrm{mM}$-Tris/HCl buffer, $\mathrm{pH} 7 \cdot 1$ (Tris buffer), and resuspended in the same buffer to an $A_{400}(10 \mathrm{~mm}$ light path) of about 1.0 to 1.2 . A sample of washed cells $(0.6 \mathrm{ml})$ was added to a disposable 'half-micro' cuvette (C. A. Greiner u. Sohne, Nurtingen) containing $0.1 \mathrm{ml}$ of an appropriate dilution of PPE antiserum and the change in $A_{400}$ with time was measured in a Gilford spectrophotometer. Normal rabbit serum was substituted for antiserum in control samples. The entire procedure was carried out at room temperature; sodium azide $(0.3 \mathrm{~mm})$ could be added to the buffer to prevent bacterial growth without interfering with the assay.

Emulsification activity. Emulsifying activity was measured as previously reported (Rosenberg et al., 1979). A sample of the cell-free supernatant fluid $(0.1$ to $0.2 \mathrm{ml})$ was added to a $125 \mathrm{ml}$ flask and brought to $7.5 \mathrm{ml}$ with Tris buffer containing $10 \mathrm{~mm}-\mathrm{MgSO}_{4}$. A solution $(0.1 \mathrm{ml})$ containing equal volumes of hexadecane and 2-methylnaphthalene was then added, and the flasks were subjected to reciprocal shaking ( 150 strokes $\left.\min ^{-1}\right)$ for $1 \mathrm{~h}$ at $30^{\circ} \mathrm{C}$. Turbidity was measured in a Klett-Summerson colorimeter (green filter) at appropriate dilutions to give readings between 50 and 150 K.U. One unit of activity is defined as that which yields a turbidity of 100 K.U. per $\mathrm{ml}$ assay mixture. Purified emulsan exhibited a specific activity of 300 units $\mathrm{mg}^{-1}$ (Rosenberg et al., 1979; Zuckerberg et al., 1979).

$V$ iscosity. The viscosity of filtered (Millipore HAWP-45) cell-free supernatant fluids was determined with a semi-micro Ubbelhode viscosimeter. The specific viscosity $\left(\eta_{\text {rel }}-1\right)$ of a given sample was calculated after measuring the flow time in duplicate at $30^{\circ} \mathrm{C}$ relative to that of Tris buffer containing $10 \mathrm{mM}-\mathrm{MgSO}_{4}$.

Phage isolation. Phages AP-2 and AP-3 were isolated in the following manner: $90 \mathrm{ml}$ of an overnight culture of 
strain RAG-1 was mixed with $10 \mathrm{ml}$ of a municipal sewage sample and shaken overnight at $30^{\circ} \mathrm{C}$. The mixture was centrifuged at $8000 \mathrm{~g}$ for $30 \mathrm{~min}$ and $10 \mathrm{ml}$ of the supernatant fluid was added to $90 \mathrm{ml}$ of a fresh culture of RAG-1. After $24 \mathrm{~h}$ growth, $0.1 \mathrm{ml}$ chloroform was added, and the mixture was centrifuged at $8000 \mathrm{~g}$ for $30 \mathrm{~min}$. The resulting supernatant fluid was passed through a Millipore Filter (HAWP-45). Serial dilutions of the filtrate $(0.1 \mathrm{ml})$ were incubated with $2 \mathrm{ml}$ of a fresh RAG-1 culture and plated in TYE medium containing $0.6 \%$ agar overlaid on $2 \%$ agar plates. Single plaques were selected and added to $2 \mathrm{ml}$ of a RAG-1 culture (25 K.U.) in TYE medium. The cultures were incubated at $30^{\circ} \mathrm{C}$ with shaking until lysis occurred. Chloroform was added and the plaque purification was repeated.

Phage sensitivity tests were performed by depositing a drop of phage stock $\left(10^{9}\right.$ plaque-forming units $\left.\mathrm{ml}^{-1}\right)$ on to plates of solid TYE medium previously spread with a given bacterial strain $(0.2 \mathrm{ml}$ of a 25 to $100 \mathrm{~K}$.U. suspension). Within $4 \mathrm{~h}$, sensitive strains developed clear zones of lysis. With phage-resistant strains, no zone of lysis could be detected even after a $24 \mathrm{~h}$ incubation period.

RESULTS

\section{Assay of agglutinability}

Addition of PPE antiserum either to a washed cell suspension of $A$. calcoaceticus RAG-1 or to the lysine auxotroph RAG-92 caused a pronounced agglutination of the bacterial cells. The kinetics of this process (Fig. 1a) showed an initial lag period followed by a marked decrease in turbidity. In contrast, normal rabbit serum had little effect on the turbidity of cell suspensions. In the absence of antiserum or in the presence of normal rabbit serum, a slow settling was observed which generally led to a $20 \%$ decrease in turbidity after $24 \mathrm{~h}$. Neither the closely related $A$. calcoaceticus BD strain nor $E$. coli were agglutinated by PPE antiserum.

The time required for the reduction of cell turbidity to one-half of its initial value (designated $t_{\frac{1}{2}}$ ) was a convenient measure of agglutinability for comparative purposes, e.g. between mutants and the parent strain or between cells grown under different conditions or harvested at different stages of growth. Low values for $t_{\frac{1}{2}}$ indicated high agglutinability, whereas higher $t_{\frac{1}{2}}$ values indicated low agglutinability. For comparative studies of this nature, a constant dilution of antiserum was used and the $t_{\frac{1}{2}}$ values were determined for test cell cultures.

Precise and reproducible differences could be demonstrated between the agglutinability of exponential phase cells and stationary phase cells (Fig. 1b). Using a 140-fold (final) dilution of the PPE antiserum, the agglutinability of exponential phase cells of strain RAG-92 gave a $t_{\frac{1}{2}}$ value of $2.7 \mathrm{~h}$ whereas the value for stationary phase cells was $3.8 \mathrm{~h}$.

\section{Cell surface mutants}

Antibody-induced sedimentation of mutagenized cells was an efficient method for selecting non-agglutinating mutants, since less than $1 \%$ of wild-type cells remained suspended following overnight agglutination at $4{ }^{\circ} \mathrm{C}$. Sequential cycles of growth and agglutination enriched the supernatant fluid for cells which failed to interact with PPE antiserum.

Forty colonies were isolated from the supernatant fluid after four cycles of growth and agglutination and examined for extracellular emulsan production, phage sensitivity and agglutinability. On the basis of antiserum-induced agglutination, 34 of the 40 isolated colonies were classified as cell surface mutants. The mutants were altered in their interaction with antiserum as evidenced by their increased $t_{\frac{1}{2}}$ values (Table 1). No significant differences in settling times of mutant or parent cells were observed in the absence of PPE antiserum. Only slight differences in $t_{1}$ values were observed between 24 and $72 \mathrm{~h}$ cultures of the parent strain, presumably because the $24 \mathrm{~h}$ culture had already entered the stationary phase of growth. Interestingly, during the stationary phase of growth, the capacity to produce surface antigen was largely regained in most of the non-agglutinating mutants. The most striking example of this phenomenon is exemplified by mutant $92-\mathrm{AB} 28$ (Table 1). In another case (mutant 92-AB15), there was almost no interaction $\left(t_{\frac{1}{2}}>24 \mathrm{~h}\right)$ between the cell surface and specific antibody regardless of the age of the culture. 

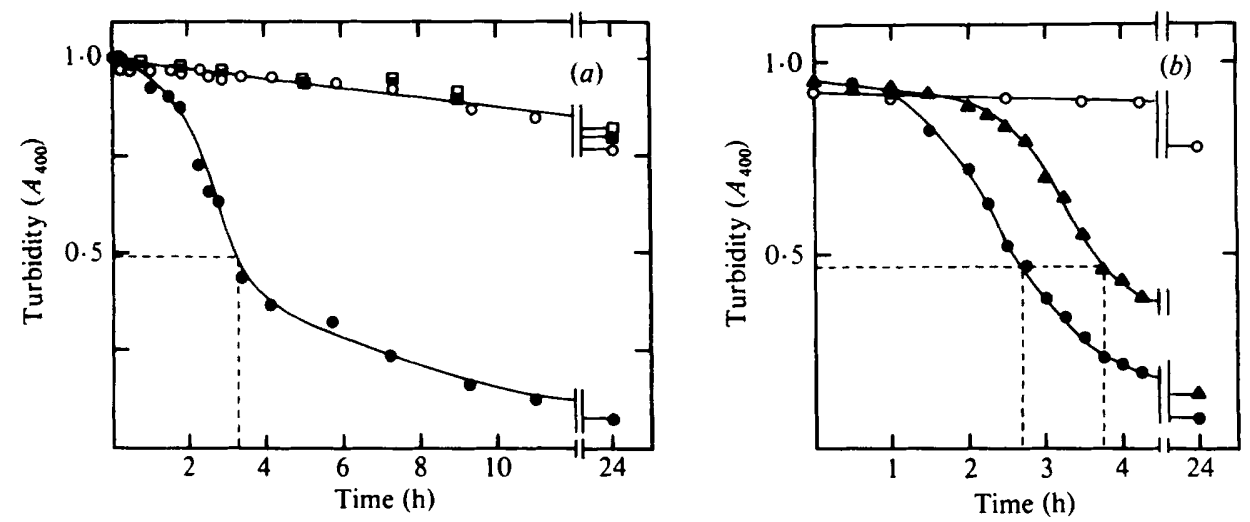

Fig. 1. (a) Kinetics of antiserum-induced agglutination of washed cells of $A$. calcoaceticus RAG-92 (24 h growth) in the presence of normal rabbit serum $(O)$ or PPE antiserum (O), both at a final dilution of 1 in 70. The same dilution of antiserum was used to examine the kinetics of agglutination of $E$. coli

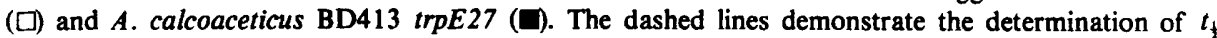

$(3.2 \mathrm{~h})$ at this particular concentration of antiserum.

(b) Effect of growth phase on the kinetics of agglutination: RAG-92 cells harvested during the exponential phase of growth, in the presence of normal rabbit serum (O) or PPE antiserum (O) at a final dilution of 1 in 140; and cells harvested during the stationary phase of growth, in the presence of antiserum ( $\boldsymbol{\Lambda})$. All values represent the average of duplicate samples derived from duplicate cultures.

Table 1. Characteristics of A. calcoaceticus RAG-1 mutants derived from the lysine auxotroph RAG-92

\begin{tabular}{|c|c|c|c|c|c|c|}
\hline \multirow{2}{*}{$\begin{array}{c}\text { A. calcoaceticus } \\
\text { RAG } \\
\text { strain }\end{array}$} & \multicolumn{2}{|c|}{ Agglutinability, ${ }^{*} t_{1}(\mathrm{~h})$} & \multicolumn{2}{|c|}{ Emulsan yield $\dagger$} & \multicolumn{2}{|c|}{ Phage sensitivity } \\
\hline & $24 \mathrm{~h}$ & $72 \mathrm{~h}$ & $E$ (units $\mathrm{ml}^{-1}$ ) & $\eta_{\mathrm{sp}}$ & AP-2 & AP-3 \\
\hline 92 (parent) & 3.7 & 4.0 & 202 & 0.25 & + & + \\
\hline 92-AB4 & $15 \cdot 5$ & 5.9 & 218 & 0.24 & + & + \\
\hline $92-\mathrm{AB} 6$ & 6.3 & 5.7 & 207 & 0.21 & - & + \\
\hline $92-\mathrm{AB} 15$ & $>24$ & $>24$ & 227 & 0.22 & + & + \\
\hline $92-\mathrm{AB} 21$ & $16 \cdot 0$ & 6.9 & 218 & 0.28 & + & + \\
\hline $92-\mathrm{AB} 24$ & 14.0 & $6 \cdot 1$ & 202 & 0.24 & + & + \\
\hline $92-\mathrm{AB} 28$ & $>18$ & $5 \cdot 3$ & 260 & 0.45 & + & - \\
\hline $92-\mathrm{AB} 38$ & 12.0 & $6 \cdot 7$ & 209 & 0.18 & + & + \\
\hline $92-\mathrm{AB} 40$ & 15.0 & 7.0 & 196 & 0.16 & + & + \\
\hline
\end{tabular}

* Cells were harvested following a growth period of 24 or $72 \mathrm{~h}$. Agglutinability is expressed as the time necessary to reduce the turbidity of cell suspensions (in the presence of antibody) to half of the original value. In all cases, a 1 in 140 dilution of antibody was used.

$\dagger$ Emulsan yield is expressed both in terms of emulsan activity $\left(E\right.$, units $\left.\mathrm{ml}^{-1}\right)$ and specific viscosity $\left(\eta_{\mathrm{sp} .}\right)$ of the cell-free culture medium (following $72 \mathrm{~h}$ growth).

It should be noted that the mutants listed in Table 1 were isolated from a single experiment. Several of these mutants, therefore, including AB4, 21, 24, 38 and 40, could be siblings. The ability to regain cell surface antigen production in the stationary phase is probably not due to a reversion, however, since single colonies isolated from stationary phase cultures exhibited the mutant phenotype. The characteristics of all mutants were stable over a period of at least 2 years.

Surprisingly, all mutants examined appeared normal with respect to extracellular emulsan production (Table 1). Both emulsifying activity and the specific viscosity of the cell-free culture media were similar to those of the parent strain. Sensitivity to both of the RAG-1 specific bacteriophages (AP-2 and AP-3) was retained in all but 2 of the 20 mutant strains 


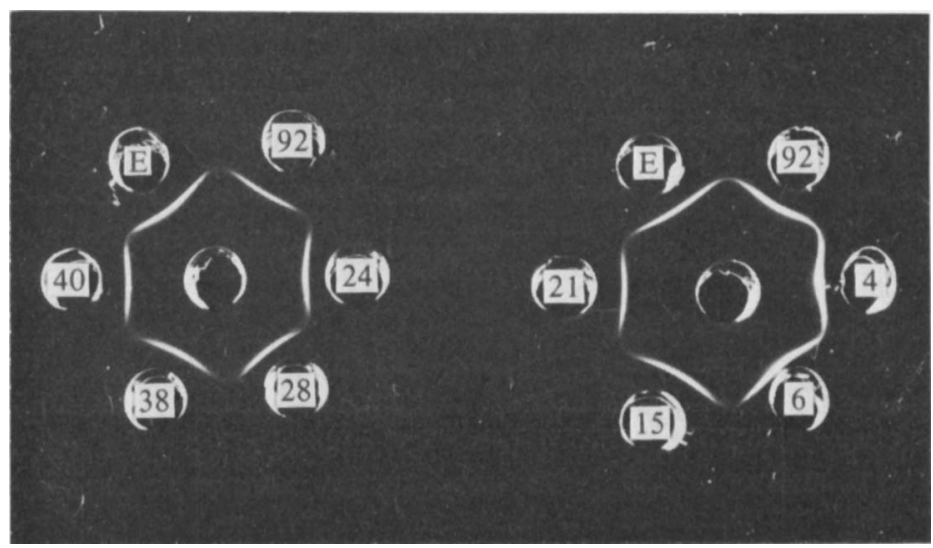

Fig. 2. Double diffusion precipitation of parent and mutant supernatant fluids and purified emulsan. The centre wells contained the PPE antiserum preparation, wells designated $\mathrm{E}$ contained purified emulsan, and wells $92,4,6,15,21,24,28,38$ and 40 contained the supernatant fluid of the corresponding parent or mutant strain.

tested: mutant 92-AB6 was resistant to phage AP-2 and mutant 92-AB28 was resistant to phage AP-3.

The cell-free supernatant fluids from the parent and mutant strains were examined by immunodiffusion (Fig. 2); the complete fusion of bands between parent and mutant supernatant fluids indicated complete identity of this particular antigenic component.

\section{DISCUSSION}

The rationale behind the present work was to exploit the action of surface-specific antiserum to generate sufficient selective pressure in order to isolate non-agglutinating cell surface mutants of Acinetobacter calcoaceticus RAG-1. The antiserum, prepared against partially purified preparations of the extracellular emulsifying agent (emulsan), had been shown to agglutinate washed cells of this strain. The agglutination induced by this particular antiserum preparation seems to be species- and even strain-specific, since no agglutination of $E$. coli cells or the $A$. calcoaceticus BD strain could be demonstrated.

The isolation of cell surface mutants by differential immunoprecipitation, as described in this communication, appears to be a useful technique. Although the 100 -fold enrichment factor generated by a single agglutination step would certainly not be sufficient to select non-agglutinating cell surface mutants, the combination of sequential growth and agglutination served to amplify the enrichment procedure. Following several cycles, a high recovery of mutants was afforded by this method. It is interesting to note that 2 of 20 non-agglutinating strains tested were found to be resistant to RAG-1 specific phages although the latter property was not used in the selection.

The following possible explanations or combinations thereof could account for the lack of interaction between a given mutant cell surface and an antibody molecule. (a) No cell-bound antigen is produced. (b) An antigen is produced, but its immunological characteristics are altered. (c) The antigen is less tightly associated with the cell surface and is released into the medium. (d) The cell surface antigen is masked, such that it is no longer accessible to the antibody.

The same concept described in this work can, in principle, be used to isolate other types of cell surface mutants, simply by substituting an alternative agglutinin. For example, polycationic macromolecules (e.g. polylysine, cationized dextran, cationized ferritin, etc.) may be used to enrich for non-capsulate or non-fimbriate mutants by sequential growth and 
agglutination cycles. In this regard DEAE-cellulose columns have already been used to separate capsulate and non-capsulate strains of Klebsiella aerogenes (Hall \& Jafri, 1980), as well as fimbriate versus non-fimbriate cells of Salmonella typhimurium (Hall et al., 1976, 1978). Likewise, mutants lacking a characteristic sugar on the cell surface may be enriched by using an appropriate lectin to agglutinate the wild-type cells.

It has recently been demonstrated that the antigenic composition of the cell surface of Salmonella dublin may differ according to the composition of the growth medium (Brown \& Jones, 1980). In this context, our current results suggest that the state of the cell surface agglutinogen(s) in parent and mutant strains of $A$. calcoaceticus RAG-1 is not constant, but varies with the phase of growth. In contrast to the parent, most of the mutants displayed higher $t_{\frac{1}{2}}$ values following $24 \mathrm{~h}$ growth. These mutants tended to regain their agglutinability in the late-stationary phase, apparently reflecting the delayed expression of the cell surface agglutinogen(s) in these strains. Since the enrichment procedure was based on growth periods of only $24 \mathrm{~h}$ alternating with the antiserum-induced agglutination steps, such mutants might have been specifically selected. Experiments are currently in progress to isolate nonagglutinating mutants after varying the length of the growth period preceding the agglutination step.

The critical question at this juncture concerns the molecular identity of the major cell surface agglutinogen(s) and its functional significance to the cell. It is interesting that the non-agglutinating mutants still appeared to produce extracellular emulsan. This could be due either to the inability of such mutants to accumulate emulsan at the cell surface, or to the presence in extracellular emulsan preparations of an additional antigen(s) also located on the cell surface. These two possibilities may be distinguished by the use of monospecific antibodies. In this regard we are currently investigating the molecular nature of the surface antigen(s) primarily responsible for agglutination.

The authors are grateful to Dr E. Juni for providing A. calcoaceticus BD413 trpE27 and to N. Kaplan for his participation in some of the agglutinability experiments. E. A. Bayer is supported by National Institutes of Health National Research Service.Award No. F32-ES5120.

\section{REFERENCES}

Bayer. E. A., SKutelsky, E., Rosenberg, E. \& GUTNICK, D. (1980). Cell surface mutants of a petroleum-degrading bacterium. Israel Journal of Medical Sciences 16, 480 (abstract).

BelsKy, I., GutNick, D. L. \& Rosenberg, E. (1979). Emulsifier of Arthrobacter RAG-1: determination of emulsifier-bound fatty acids. FEBS Letters 101, 175-178.

Brown, G. T. H. \& Jones, P. W. (1980). Crossed immunoelectrophoresis and crossed-line immunoelectrophoresis of Salmonella dublin antigens. Jour nal of General Microbiology 116, 315-322.

FAUlK. W. P. \& HouBA, V. (1973). Immunological reactions with chromic chloride-treated erythrocytes. Journal of Immunological Methods 3, 87-98.

HALL, A. N. \& JAFRI, S. S. A. (1980). Gradient elution from a DEAE-cellulose column of capsulate and non-capsulate strains of Klebsiella aerogenes. Journal of General Microbiology 117, 263-265.

Hall, A. N., Hogg, S. D. \& Phillips, G. O. (1976). Gradient eluton of Salmonella typhimurium and Escherichia coli strains from a DEAE-cellulose column. Journal of Applied Bacteriology 41, 189192.

Hall, A. N., Hogg, S. D. \& Phillips, G. O. (1978). Influence of growth phase on the gradient elution of Salmonella typhimurium from DEAE-cellulose. Journal of Applied Bacteriology 44, 215-223.

Ouchterlony, O. (1958). Diffusion-in-gel methods for immunological analysis. Progress in Allergy 5, $1-78$.

Reisfeld, A., Rosenberg, E. \& Gutnick, D. L. (1972). Microbial degradation of crude oil: factors affecting the dispersion in seawater by mixed and pure cultures. Applied Microbiology 24, 363-368.

RoSENBERG, E., ZuCKerberG, A., Rubinowitz, H. \& GuTNICK, D. L. (1979). Emulsifier of Arthrobacter RAG-1: isolation and emulsifying properties. $A p$ plied and Environmental Microbiology 37, 402-408.

Zuckerberg, A., Diver, A., Peeri, Z., Gutnick, D. L. \& ROSENBERG, E. (1979). Emulsitier of Arthrobacter RAG-1: chemical and physical properties. Applied and Environmental Microbiology 37, 414-420. 